\title{
RESSONÂNCIAS HISTÓRICAS DAS RELIGIÕES AFRO-BRASILEIRAS EM SANTA CATARINA: FLORIANÓPOLIS, ITAJAII E JOINVILLE'
}

HISTORICAL RESONANCES OF AFRO-BRAZILIAN RELIGIONS IN SANTA CATARINA STATE: FLORIANÓPOLIS, ITAJAII AND JOINVILLE

Luciano da Silva Candemi Universidade Federal do Paraná lucianocandemil@hotmail.com 


\section{Resumo}

Trata-se de um estudo sobre o processo histórico das religiões afro-brasileiras em Santa Catarina, em especial a umbanda e o candomblé na região entre Florianópolis e Joinville. Visando compreender por que estas religiões estão intimamente relacionadas, foi realizada uma investigação histórica amparada pelas lentes da etnomusicologia (BLACKING, 2000), antropologia (LAPLANTINE, 2012) e dos estudos culturais (GARCÍA CANCLI$\mathrm{NI}, 2015)$. Diante da escassez de pesquisas sobre esta temática na região, foi adotada como estratégia o conceito das ressonâncias históricas. Foram utilizadas bibliografias locais da área da história, antropologia, etnomusicologia, ciências humanas e de afrorreligiosidades. Conta-se também com relatos orais e intensa experiência de campo. Por conta de fatores geográficos, políticos e econômicos, detectamos que a história do candomblé em Santa Catarina passa pela umbanda, kardecismo, benzedeiras, curandeiros e pela figura do caboclo indígena, com vínculos no Rio de Janeiro e na Bahia. Diante das metamorfoses culturais, as religiões afro-brasileiras catarinenses são caracterizadas pela liberdade religiosa e pelo hibridismo doutrinal.

Palavras-chave: Religiões afro-brasileiras. Candomblé. Umbanda. Hibridismo doutrinal.

\section{Abstract}

This is a study on the historical process of Afro-Brazilian religions in Santa Catarina State, especially Umbanda and Candomblé in the region between Florianópolis and Joinville. In order to understand why these religions are so closely related, a historical investigation was carried out, supported by the lens of Ethnomusicology (BLACKING, 2000), Anthropology (LAPLANTINE, 2012), and Cultural Studies (GARCÍA CANCLINI, 2015). Given the scarcity of research on this topic in the region, historical resonances were adopted as a strategy. Local bibliographies of History, Anthropology, Ethnomusicology, Humanities and Afro-religiosity were used. There are also oral reports and intense field experience. Due to geographical, political and economic factors, the history of Candomble in Santa Catarina goes through Umbanda, Kardecismo, healers and the figure of the indigenous caboclo; with bonds in Rio de Janeiro and Bahia. Faced with cultural metamorphoses, the Afro-Brazilian religions of Santa Catarina are characterized by religious freedom and doctrinal hybridism.

Keywords: Afro-Brazilian Religions. Candomblé. Umbanda. Doctrinal hybridism.

\footnotetext{
1 O presente trabalho foi realizado com apoio da Coordenação de Aperfeiçoamento de Pessoal de Nível Superior - Brasil (Capes) - Código de Financiamento 001.

2 Luciano da Silva Candemil é natural de Florianópolis. Atua como músico, percussionista, compositor, professor, pesquisador e produtor musical. Atualmente é doutorando em Etnomusicologia na Universidade Federal do Paraná (UFPR), bolsista Capes e membro do Grupetno. Tem Mestrado em Etnomusicologia na Universidade do Estado de Santa Catarina (Udesc). Tem as seguintes titulações cursadas na Universidade do Vale do Itajaí (Univali): Especialização em Educação Musical, Licenciatura em Música e Bacharelado em Música (percussão popular).
} 


\section{Ressonâncias históricas}

O presente estudo tem como objetivo principal compreender o processo histórico da constituição das religiões afro-brasileiras em Santa Catarina, principalmente da região entre Florianópolis e Joinville, com uma atenção especial a Itajaí, que está situada no meio dessas cidades, as duas maiores em densidade populacional do estado. Este trabalho faz parte de um projeto de Doutorado em Música que se concentra em torno da casa religiosa Ilê Alaketú Oyá Onirá Asé, conhecida também como o Terreiro do Pai Jean, um terreiro de candomblé ketu, mas que também realiza rituais e festas de umbanda.

Acontece que, se a pesquisa tem como foco a música produzida neste terreiro, situado em Itajaí, torna-se necessário para um estudo de etnomusicologia considerar o contexto cultural local e regional para alcançar o entendimento das práticas musicais e religiosas (MERRIAM, 1964; SEEGER, 2008; BLACKING, 2000; HALL, 2003). No entanto, no decorrer das atividades, detectamos raríssimas informações sobre a história da religiosidade de matriz africana nesse município, que podem ser encontradas nos trabalhos de Costa e Silva (2010), D'Ávila (1982, 2018) e Rodrigues (2016), o único voltado exclusivamente para a temática.

Diante da dificuldade para levantar os dados sobre a história do candomblé e da umbanda em Itajaí, foi adotada como estratégia de pesquisa o que chamamos de ressonâncias históricas. Partindo dos princípios da acústica, na qual ressonância designa a repercussão do som, vamos imaginar que os fatos históricos que aconteciam nas cidades de Florianópolis e Joinville devem ter repercutido ou também aconteciam em Itajaí na mesma época. Nessa direção, será levado em conta o estudo de Tramonte (2001), que identificou relações entre as manifestações afro-brasileiras entre Itajaí e Florianópolis.

Em outras palavras, tendo em vista a configuração geográfica (Fig. 1), acredita-se que é possível encontrar ressonâncias históricas entre estas três cidades. Especula-se que alguns fatos históricos que aconteciam nas duas cidades extremas podem ter acontecido também em Itajaí e vice-versa, ou então acabavam de alguma forma influenciando outros acontecimentos futuros. Além disso, vamos considerar fatos históricos nacionais que geraram algum reflexo contemporâneo nestas mesmas cidades. Desse modo, por meio da indução será possível extrair certas conclusões (LAPLANTINE, 2012, p.57).



Fig. 1: Mapa político de Santa Catarina. Fonte: Mapasblog (2011). 
Para "imaginar o passado como obra aberta" (RASCKE, 2010, p.28), é preciso verificar que fatos históricos estão diretamente relacionados com a formação da sociedade catarinense, em especial com a trajetória da população negra. Uma perspectiva oriunda dos estudos culturais (HALL, 2003) sugere observar como as identidades culturais são transformadas nas diásporas africanas. Em tempos modernos, ressalta-se que os espaços e as experiências perpassam fronteiras geográficas, étnicas, sociais, religiosas e ideológicas (GILROY, 2012, p.110).

Então, para compreender a adaptação das práticas religiosas, entre elas as atividades musicais, temos que iniciar colocando holofotes nas experiências dos homens e mulheres de origem negra. Conforme sugere Blacking (1995), cada cultura tem um ritmo particular, como resultado de um conjunto de experiências conscientes, individuais e coletivas, que são ordenadas por ciclos de ordem física, econômica, genealógica, política e espiritual, todas que tenham significado (BLACKING, 1995, p.34).

Se os fatos sociais só podem ser entendidos em relação a outros fatos sociais (LAPLANTINE, 2012, p.89), para efetuar esse trabalho historiográfico buscou-se seguir a linha do tempo para identificar pontos importantes da história, geografia, economia e da política, que de alguma forma estão vinculados às religiões afro-brasileiras, com uma atenção especial voltada para a umbanda e o candomblé, os quais demonstram estar fortemente ligados nessa região. Para tal, foram utilizadas bibliografias da área da História (MACHADO, 2012; D'ÁVILA, 2018; COSTA; SILVA, 2010; SILVA 2016), da Antropologia (LEITE, 1996; NUER, 2017), das Ciências Humanas (TRAMONTE, 2001), além de materiais sobre afrorreligiosidades (ORTIZ, 1999; PEDRO, 1988; MARTINS, 2011; BRAGA, 1997; BASTIDE, 1971). Tendo Da Silva Selau (2004) e Castillo (2010) como alicerces, foram utilizados relatos orais obtidos em conversas informais, com o objetivo de enriquecer a pesquisa e possibilitar novos olhares.

Em paralelo, conta-se com a experiência da "participação ativa" (BRAGA, 2013, p.8) acumulada ao longo dos últimos sete anos, a qual contabiliza mais de duzentas visitas de campo aos terreiros de umbanda e candomblé, tanto em Santa Catarina quanto na Bahia, contemplando diferentes atuações como pesquisador: observando, anotando, filmando, fotografando, tocando, aprendendo, ensinando ou simplesmente participando. "Para compreender um fenômeno social total, é preciso aprendê-lo totalmente, isto é, de fora com uma 'coisa', mas também de dentro como uma realidade vivida" (LAPLANTINE, 2012, p.91).

Por fim, de acordo com o Nuer (2017), será mostrado que, nessa região catarinense, o desenvolvimento das religiões afro-brasileiras está condicionado a diversos fatores socioeconômicos, aos movimentos migratórios voluntários e forçados, bem como aos processos de transmissão dos saberes religiosos que envolvem uma rede de conexões locais, regionais e nacionais (NUER, 2017, p.102). 


\section{Negro em terra de branco ${ }^{3}$}

As práticas culturais de matriz africana, em especial as religiões afro-brasileiras, ainda hoje necessitam de uma maior valorização, em especial na região Sul brasileira, "onde as origens africanas são renegadas e as raízes europeias enaltecidas" (NUER, 2017, p.9). "Não é que o negro não seja visto, mas sim que ele é visto como não existente" (LEITE, 1996, p.40). Nesse sentido, almeja-se que o breve panorama histórico apresentado aqui, elaborado por meio de fatos relacionados às pessoas negras que vieram para esta região, seja útil para romper com alguns paradigmas, diminuindo o preconceito e, sobretudo, para compreender a formação social catarinense.

Essa invisibilidade historiográfica dos negros foi constatada no estado do Rio Grande do Sul (OLIVEN, 1996; BRAGA, 1997; ORO, 1996) e em Santa Catarina (COSTA; SILVA, 2010; TRAMONTE, 2001; LEITE, 1996; RASCKE, 2016). Mas, independentemente da falta do reconhecimento público e oficial, as pesquisas podem encontrar uma rede de conexões diaspóricas, locais, regionais, nacionais e internacionais, como por exemplo os trabalhos de Herskovits e de Bastide realizados no estado do Rio Grande do Sul, respectivamente em 1942 e 1945 (NUER, 2017, p.17-38; BRAGA, 2013, p.16).

Conforme aponta Oliven (1996), apesar de ter havido escravos em terras gaúchas desde a primeira metade do século XVIII e de ser quase $30 \%$ da população do estado no início do século seguinte, até hoje a população de origem africana não faz parte da formação da identidade regional (OLIVEN, 1996, p.20-26). Em certo período os negros eram quase $50 \%$ da população estadual (BRAGA, 1997, p.11). Por outro lado, Bastide constatou a existência de 13 casas de culto afro em Porto Alegre, em 1937, e de 57 casas em 1942 (OLIVEN, 1996, p.27). De acordo com dados mais recentes, Oro (1996) estimou que no ano de 1996 havia em torno de 30 mil terreiros no estado do Rio Grande Sul (ORO, 1996, p.153), dos quais 2 mil estariam na capital (ORO, 2002, p.349). Atualmente, os números devem ser mais expressivos, podendo chegar a $50 \mathrm{mil}^{4}$ terreiros, dos quais 3 mil estariam em Porto Alegre e 600 em Pelotas.

Como veremos, em Santa Catarina os números são bem menores por conta do seu processo histórico. Por exemplo, segundo dados do mapeamento realizado pelo Nuer (2017), na região da Grande Florianópolis, a capital, existem cerca de 210 instituições afrorreligiosas, contemplando uma "comunidade de santo" em torno de 50 mil pessoas (NUER, 2017, p.12). Desse montante, foram catalogados 109 em Florianópolis, 60 em São José, 28 em Palhoça e 13 em Biguaçu (NUER, 2017, p.51).

Por conta da sua característica geográfica, diferente da do estado vizinho, no período colonial o estado catarinense não era uma região economicamente atrativa, seja para as largas plantações de produtos tropicais, seja para o desenvolvimento da pecuária. Desse modo, a colonização iniciou com os portugueses no litoral, com uma economia local caracterizada pela pequena e média propriedade (LEITE, 1996, p.41). Então,

\footnotetext{
3 Título retirado do livro Negro em terra de branco: escravidão e preconceito em Santa Catarina no século XIX (PEDRO, 1998).

4 Dados fornecidos por pessoas vinculadas às religiões afro-brasileiras de Pelotas durante conversas informais no período do XXIX Congresso da Anppom, realizado em agosto de 2019 nesta cidade.
} 
por não fazer parte dos centros com maior dinamismo comercial, não foi possível a aquisição de grandes quantidades de escravos negros (PEDRO, 1988, p.9.), o que acaba condicionando a formação social de Santa Catarina.

No início, os vicentinos, ${ }^{5}$ açorianos ${ }^{6}$ e madeirenses, ${ }^{7}$ vindo com famílias pequenas, se estabeleceram na costa, limitando-se às atividades de subsistência. Depois, como estes não mostraram interesse em ocupar as terras do interior do estado, foi iniciado um projeto político de modernização e de embranquecimento da sociedade catarinense (LEITE, 1996, p.38). A partir de 1850, esta região foi massivamente oferecida aos imigrantes europeus, que aos poucos acabaram superando a quantidade de trabalhadores escravos (LEITE, 1996, p.50). Porém, a "visibilidade [que foi e que é] dada às etnias europeias não significa a total ausência de outros grupos étnicos" (COSTA, 2010, p.32). Ou seja, pouca quantidade proporcional não significa ausência.

Em virtude desses fatores econômicos e geográficos, a composição social em Santa Catarina não dependia tanto da mão de obra escrava, que servia em muitos casos apenas para demonstrar prestígio social, para serviços domésticos ou para ajudar nas pequenas lavouras ao lado dos seus senhores. Conforme aponta Pedro, o indivíduo negro era considerado um estranho, um intruso que tinha que ser tolerado (PEDRO, 1988, p.7).

Segundo Leite (1996), o estado catarinense é uma ${ }^{8}$ das regiões do país com menor percentual de negros, apesar de ter uma das maiores diversidades étnicas (LEITE, 1996, p.37). No entanto, a comunidade negra foi muito importante para a economia local entre os séculos XVIII e XIX (NUER, 2017, p.50) e a sua forma de participação atingiu uma peculiaridade em razão da realidade regional.

A região de Florianópolis, na época chamada de Desterro, foi um importante centro de caça e produção de óleo de baleia, no qual os escravos eram mão de obra importante (NUER, 2017, p.50-54). Além disso, no início do século XIX, já tinha estabelecido uma rota comercial com o Rio de Janeiro (RASCKE, 2010, p.37). Nessa época, os principais serviços exercidos pelos homens negros eram de estivador, transporte de mercadorias, sapateiros, além do trabalho na pesca artesanal e nas lavouras familiares; enquanto as mulheres negras trabalhavam como quitandeiras, lavadeiras, cozinheiras e outros serviços domésticos (RASCKE, 2010, p.43-52).

Nesse período, em alguns momentos a quantidade de escravos atingiu patamares expressivos. Por exemplo, entre 1797 e 1819, a população de origem negra girava em torno de 21\% da população catarinense, chegando a quase 24\% em 1831 (PEDRO, 1988, p.19). Em Desterro, os números são maiores. De 1796 a 1810, havia entre 26\% a 32\% de escravos, e em 1831 chegou à marca de 40\% (PEDRO, 1988, p.20). Mas, como dito anteriormente, com o passar dos anos, esses números foram diminuindo com a chegada da imigração europeia. Este fato também aconteceu no Rio Grande do Sul (BRAGA, 2013, p.9).

\footnotetext{
$5 \quad$ Provenientes da Capitania de São Vicente.

6 Provenientes do Arquipélago dos Açores.

7 Provenientes do Arquipélago da Madeira.

8 Segundo Braga (1997) e Oro (2002), Santa Catarina e Rio Grande do Sul são considerados os estados mais brancos do país (BRAGA, 1997, p.1; ORO, 2002, p.361).
} 
Além da condição de escravo, era negado às pessoas negras o direito de manter a sua identidade cultural e religiosa, inclusive por meios legais. Se até o final do século XIX muitos afrodescendentes "costumavam fazer seus batuques e danças pela rua da cidade" (RASCKE, 2010, p. 118), por outro lado, as "manifestações com caráter de reafirmação da cultura africana ou afro-brasileira eram [...] sistematicamente reprimidas", conforme consta no art. 21 da Postura da Câmara da Villa de São José, com data de 3/6/1836 (PEDRO, 1988, p.34); no Código de Posturas do Município de Itajaí, em 1868 (D'AVILA, 2018, p.348); e na lei municipal de Florianópolis de 1831 (MENÊSES, 1973, p.12 apud NUER, 2017, p.78).

Uma das manifestações reprimidas no litoral de Santa Catarina, principalmente na região entre Florianópolis e Joinville, era o Cacumbi, ${ }^{9}$ também chamado de Catumbi, Quicumbi ou Moçambique, uma variante das congadas, uma dança com traços das tradições africana e portuguesa. Atualmente, existe apenas o Catumbi de Itapocu, de Araquari, com mais de duzentos anos de história e que ainda utiliza os mesmos dois tambores, com formato tipo caixa do divino (CANDEMIL; PAIVA, 2016, p.12).

Para Silva (2013), o Cacumbi era uma festa em homenagem a Nossa Senhora do Rosário e São Benedito, praticada por descendentes de escravos libertos, envolvendo dança, música, trajes, estandartes e coroação de reis e rainhas (SILVA, 2013, p.1-3). No município de Itajaí, também há mais de duzentos anos, havia a Congada de São Sebastião, que estava vinculada às festas realizadas pelas irmandades de negros, em especial à Festa de Nossa Senhora do Rosário (SILVA, 2010, p.63).

Então, por conta da repressão, uma das formas de resistência era associar-se a alguma irmandade católica, com destaque para a Irmandade de Nossa Senhora do Rosário e São Benedito dos Homens Pretos, fundada por negros em 1750 em Desterro (RASCKE, 2016, p.91). Vale ressaltar que essa irmandade era devota dos mesmos santos homenageados pelas danças do Cacumbi. Na época, "as irmandades eram as únicas religiosidades permitidas, embora sob rigorosas formas de controle da igreja católica" (NUER, 2017, p.78). Por conta disso, "as irmandades foram fundamentais para a transformação, para a manutenção das culturas africanas e afro-brasileiras, além da introdução do negro na sociedade de classes" (COSTA, 2010, p.17). Conforme García Canclini (2015), as comunidades culturais são espaços que servem para intensificar os vínculos e ajustar as ações de seus membros (GARCÍA CANCLINI, 2015, p.314).

Rascke (2010) informa que, além da devoção católica, a irmandade citada acima tinha como objetivo garantir a liberdade e uma boa morte aos seus filiados e filiadas (RASCKE, 2010, p.54-64), propósito em comum com a Irmandade da Nossa Senhora da Boa Morte, de Cachoeira (BA), embora esta fosse restrita somente às mulheres negras. A Irmandade situada em Desterro era composta por pessoas de origem africana, como os monjolos, congos, angolas, minas e benguelas, como também crioulos e pardos, e pessoas do continente europeu, como os italianos, espanhóis e alemães (RASCKE, 2016, p.95). Observa-se a ausência de negros de origem ketu e jeje nesse período, etnias formadoras dos candomblés ketu e jeje na Bahia.

9 Para mais detalhes, ver: ALVES, Jucélia Maria. Cacumbi: um aspecto da cultura negra em Santa Catarina. Florianópolis: UFSC, Secretaria da Cultura e do Esporte de Santa Catarina, 1990. 
Embora não tenham sido encontrados documentos e detalhes sobre a música e instrumentos, Rascke (2010) aponta que, dentre as atividades religiosas, estavam a organização de festas, procissões, coroação de reis e rainhas (RASCKE, 2010, p. 62-64), dentre as quais as evidências apontam para o cacumbi.

\section{A cidade de Itajaí}

O município de Itajaí está situado entre o rio Itajaí-Açu e o oceano Atlântico, no litoral norte do estado de Santa Catarina, na região Sul do Brasil. Atualmente, tem uma população estimada em aproximadamente 220 mil pessoas (IBGE, 2020, p.1). Conforme dados fornecidos pela prefeitura, em termos econômicos, Itajaí se destaca como um dos maiores complexos portuários do país, sendo o Porto de Itajaí o "segundo porto brasileiro em movimentação de cargas em contêineres, bem como o maior exportador de carnes congeladas do Brasil" (ITAJAí, 2020, p.1). Tal conquista pode estar vinculada à sua vocação comercial e geográfica, pois, segundo D'Ávila (1982), por conta do comércio de madeiras, transportadas em veleiros no final do século XIX, Itajaí já mantinha contatos com negociadores da cidade do Rio de Janeiro e de Santos (D'ÁVILA, 1982, p.39). Nos dias atuais, "o município concilia as atividades portuárias, petrolíferas, comercial e universitária" (RODRIGUES, 2016, p.8).

Esta localidade há muito tempo tem sido o destino de muitos moradores. Conforme aponta D’Ávila (1982), inicialmente os índios carijós, primitivos guaranis, moravam à beira-mar; depois vieram os índios botocudos, pertencentes ao grupo Tapuia, hoje Kaigangues, que preferiram se estabelecer nas proximidades da foz do rio Itajaí-Açu; e depois vieram os homens brancos (D'ÁVILA, 1982, p.21). Por conta dessa trajetória indígena, Itajaí (originalmente Itajahy) é uma palavra de origem tupi-guarani que pode significar tanto "rio das pedras" ou "rio dos taiás", sendo taiá uma espécie de erva (D'ÁVILA, 1982, p.15-16).

Girando em torno do interesse pela navegação, a cidade de Itajaí foi inicialmente colonizada por portugueses, no século XVIII, e depois por alemães, no século XIX (ITAJAÍ, 2020, p.1). Para D'Ávila (1982), os europeus chegaram nessa ordem: os vicentistas, os açorianos, os alemães, os italianos e, em número menor, vieram os suíços e os sírio-libaneses (D'ÁVILA, 1982, p.32). D’Ávila (1982) registra também que, desde 1659, o território de Itajaí já recebia moradores de outras localidades, como por exemplo da Vila de São Francisco do Sul (hoje cidade), de Desterro (Florianópolis), de Porto Belo, todas estas cidades catarinenses, bem como de Paranaguá, do Paraná (D'ÁVILA, 1982, p.17).

\section{Negros em Itajaí ${ }^{10}$}

No que se refere aos registros históricos da população negra na cidade de Itajaí, segundo D'Ávila (2018), "os primeiros escravos de origem africana chegaram à foz do Itajaí junto com os moradores luso-brasileiros estabelecidos no século XVIII", e que, 
no ano de 1790, estima-se que havia em torno de 40 pessoas negras nessa localidade (D'ÁVILA, 2018, p.109). Para Costa e Silva (2010), "muito antes de Itajaí tornar-se Vila, em 1860, os negros trazidos da África e de outras províncias do Brasil já estavam aqui na condição de escravos, embora as datas e os registros oficiais os ocultem" (COSTA; SILVA, 2010, p.9).

Esses escravos que vieram para Itajaí "eram adquiridos de comerciantes negreiros que os importavam principalmente do grande mercado escravista do Rio de Janeiro", mas que faziam um desembarque em Desterro, bem como chegavam diretamente da África para o porto de Itajaí (D'ÁVILA, 2018, p.112). Ao analisar documentos de compra e venda de escravos, Silva (2010) detectou algumas possíveis procedências africanas, como congo, benguela e monjolo (SILVA, 2010, p.125-126). Novamente temos a ausência das origens ketu e jeje.

Em relação aos documentos citados acima, D'Ávila $(1982 ; 2018)$ sinaliza que "o contingente populacional de origem africana de Itajaí é pela primeira vez referido em [1838], quando, de um total de 1.404 almas, se contavam 163 negros, significando, portanto, uma percentagem de 11,6\% da população" (D'ÁVILA, 1982, p.32). Sobre a população escrava registrada em Itajaí, temos os seguintes números: em 1838 havia 163 escravos; 190 em 1840; 822 em 1856; 831 em 1874; 692 em 1883; 608 em 1884; 524 em 1886 e 456 em 1887 (D'ÁVILA, 2018, p.115). A título de ilustração, em torno de 1850 havia cerca de 1.600 escravos em Pelotas, superando a marca de $50 \%$ da população local (ORO, 2002, p.348).

Segundo Silva (2010), embora na condição de escravos, os negros "estiveram presentes na formação da história de Itajaí" (SILVA, 2010, p.127). Eles trabalharam principalmente na agricultura, em pequenas e médias propriedades, e em serviços domésticos, mas, por conta do crescimento do Porto de Itajaí, a mão de obra escrava também passou a ser usada pelo comércio local, nas atividades portuárias de carga e descarga e de marinharia (D'ÁVILA, 2018, p.110-114).

No período pós-abolição, depois de 1888, os negros libertos passaram a constituir certos territórios locais com o objetivo de preservar as suas tradições, lutando pela "resistência e sobrevivência de práticas de culto afro-brasileiro" (D'ÁVILA, 2018, p.119). Inclusive, Silva (2010, p.89-106) tem um estudo que apresenta detalhes de um quilombo urbano que havia na cidade em meados do século XX, entre 1930 e 1960. Hoje em dia, "a religiosidade dos itajaienses provém de quatro fontes religiosas: catolicismo romano, evangelismo protestante, kardecismo espírita e cultos africanos" (D'ÁVILA, 2018, p.119).

\title{
Itajaí e a mistura das "águas"
}

\author{
"Itajaí-Açu, o maior rio das costas catarinenses, [...] \\ percorre 190 quilômetros de caminho até se lançar no \\ Oceano Atlântico aqui em frente à nossa cidade. \\ Nessa caminhada, recebe muitas águas de outros rios e \\ ribeirões que são seus afluentes" \\ Edison D'Ávila
}


Na parte do trabalho de campo realizado nos terreiros de candomblé da Bahia, em pequenas viagens entre 2017 e 2019, tanto na capital, Salvador, como nas cidades do Recôncavo Baiano, Cachoeira, São Félix e Muritiba, por várias vezes escutei o termo "água" como uma expressão do conceito de "nação". Durante algumas conversas informais com o "povo de santo", quando falávamos sobre a origem do candomblé e das mudanças ocorridas ao longo tempo até os dias atuais, alguns iniciados mencionaram que muitas coisas haviam mudado, porque "as águas tenham sido misturadas". Deduzi que eles queriam dizer que o encontro e a mistura entre origens étnicas diferentes, aqui entendidas como nações, ou como tipos de candomblé, ketu, jeje, angola, ijexá, ewe-fon etc., provocou a adaptação de certas atividades e expressões religiosas. Portanto, em outras palavras, eu interpretei que "mistura das águas" significava a "mistura das águas de candomblés", ou seja, a "mistura das nações", "mistura dos axés", "mistura das energias". Partindo dessa metáfora, surgiu a ideia de introduzir o texto em epígrafe para fazer uma analogia com o processo histórico e religioso da cidade de Itajaí. Relacionando a "mistura das águas" com o entrelaçamento de etnias diferentes que se encontram num espaço específico durante um determinado curso de tempo, sugiro considerar a frase "receber muitas águas de outros rios e ribeirões" como a chegada de pessoas de diversos lugares que trouxeram consigo uma herança cultural. Vale ressaltar que "a hibridez tem um longo trajeto nas culturas latino-americanas" (GARCÍA CANCLINI, 2015, p.326). Dessa maneira, podemos pensar que a trajetória do maior rio catarinense pode simbolizar a formação da cidade de Itajaí e a intensa relação que há entre as práticas religiosas da umbanda com o candomblé, e vice-versa, bem como o interesse de encontrar certas ressonâncias históricas entre as cidades de Itajaí, Florianópolis e Joinville.

Portanto, como já foi dito, o objetivo deste estudo é "misturar as águas", misturar os fatos históricos para compreender a formação do cenário afrorreligioso no litoral catarinense, com ênfase para a região de Itajaí. Seguimos adiante nessa direção. Se parecer que o texto caminha em espiral, trata-se de uma influência da abordagem antropológica que permite que os pontos principais de um estudo sejam retomados sob novos pontos de vista (LAPLANTINE, 2012, p.32).

\section{As religiões afro-brasileiras em Santa Catarina}

No estado de Santa Catarina, a comunidade do povo de santo "existe há mais de 70 anos [...] com suas estratégias variadas de se colocar no mundo e cultuar sua religiosidade" (NUER, 2017, p.18). Mas como será que essa cultura se estabeleceu ao longo do tempo nessa região? Sem a intenção de construir uma nova história, vou procurar juntar fatos que se aproximem do real (LAPLANTINE, 2012, p.110), quem sabe até de um real imaginário, mas que façam emergir algumas respostas.

Desde 1750 nas cidades de Florianópolis, Laguna, São Miguel, São Francisco do Sul (bem próxima de Joinville) e Itajaí, já é possível encontrar relatos de práticas culturais afro-brasileiras realizadas por pessoas filiadas às irmandades negras de alguma confraria católica (NUER, 2017, p.78). Em virtude disso, podemos imaginar que em algumas 
atividades eram utilizados instrumentos de percussão, como é o caso dos tambores do cacumbi, visto anteriormente.

Sendo assim, é possível questionar sobre as outras práticas não institucionalizadas que aconteciam, apesar de serem perseguidas com o apoio de leis. Como consequência, certas crenças e costumes foram adaptados para conseguir sobreviver, como sugere Ortiz (1999): "Essas tradições assumem, em diferentes áreas do país, diferentes ritos e nomes locais, derivados de tradições africanas diversas (ORTIZ, 1999, p.21). O problema é que justamente foram os elementos mais característicos da religiosidade afro-brasileira que foram reprimidos, como a dança e a percussão.

Conforme aponta Tramonte (2002, p.13), nesse cenário de preconceito, perseguição e invisibilidade, em meados de 1830, na região de Desterro, temos notícia da presença das benzedeiras e dos curandeiros, chamadas de práticas de feitiçaria, enquanto na mesma época já surgiam os primeiros terreiros de candomblé na Bahia. As religiões afro-brasileiras surgem em Santa Catarina em meados do século XIX, a partir de Desterro, como resultante de uma rede complexa de relações formada por rezadeiras, benzedeiras e curandeiros, que praticavam a caridade por meio de consultas individuais para pessoas pobres (TRAMONTE, 2001, p.17).

Na capital do estado, Florianópolis, conhecida também por llha da Magia, havia muitas benzedeiras. Essa tradição continua e é ainda tão forte que a cidade ganhou recentemente um guia de benzedeiras e benzedores, chamado Benze, é Bem dizer, que é um mapa com a localização de cada um (AMORIM, 2018). Segundo Tramonte (2001), as benzedeiras, ${ }^{11}$ em sua maioria, eram das classes sociais mais baixas, brancas e negras, "que possuíam grande prestígio pelo poder a elas atribuído de cura espiritual e física, com o auxílio de rezas e ervas, numa clara mistura de terapêutica corporal e espiritual" (TRAMONTE, 2001, p.20).

No passado recente, uma das benzedeiras mais famosas foi a senhora Lídia Luiza dos Santos, "nascida no dia 10 de maio de 1907 e que aos vinte e poucos anos começou a ter tonturas, desmaios, visões e passou então a receber uma preta velha que se apresentou como Vó Estefânia" (NUER, 2017, p.85). Ressalta-se que não é possível afirmar que todas as benzedeiras tivessem algum desenvolvimento espiritual relacionado com as entidades da atual umbanda. Por outro lado, a presença das benzedeiras nunca foi uma exclusividade da capital do estado e do seu entorno. Conforme alguns relatos informais, a prática do benzimento era muito comum nas cidades de Governador Celso Ramos, Tijucas, Porto Belo, Itajaí, Brusque e até Blumenau. Era comum também no município de Laguna, terra natal de meus pais e avós paternos, onde por várias vezes a minha mãe, Maria da Graça, nos levava (eu e meus irmãos) para sermos benzidos. As benzedeiras mais conhecidas eram a tia Mimi e a dona Minervina. A minha mãe relatou que a dona Minervina, quando era jovem, foi levada de Laguna para Criciúma para ser internada num hospital psiquiátrico. No entanto, ela foi liberada pela equipe médica, que recomendou

\footnotetext{
11 Não foram encontrados dados que comprovassem a origem das práticas de benzimento. No entanto, indícios apontam que as práticas de cura vieram dos escravos africanos e dos indígenas que aqui habitavam. No passado, os termos benzedeiras, rezadeiras e curandeiros estariam vinculados aos atendimentos sem "incorporação espiritual", e o termo feitiçaria para a ocorrência de "transes mediúnicos".
} 
que ela trabalhasse como benzedeira. Essa situação demonstra que muitas benzedeiras, curandeiros, mães e pais de santo iniciaram a sua mediunidade ${ }^{12}$ motivados aparentemente por problemas mentais ou físicos. Esse é o caso do Pai Vilson, ${ }^{13}$ de Tijucas, que com sete anos de idade tinha "certas convulsões". Segundo a sua mãe, as pessoas pensavam que ele tinha ataques epilépticos, mas na verdade ele já estava sendo "chamado" pela entidade Caboclo Ubirajara Flecheiro, fato confirmado anos depois.

Um exemplo da presença de benzedeiras na região do Vale do Itajaí é relatado por dona Alcina Venâncio de Souza, ${ }^{14}$ com 73 anos de idade, que nasceu em Brusque e que com um ano de idade foi morar na cidade de Tijucas. Ela é "mãe carnal" do sr. Vilson José de Souza, o Pai Vilson, o babalorixá da Associação Beneficente Tenda de Umbanda Caboclo Ubirajara Flecheiro, um terreiro das 7 Linhas de Umbanda, onde eu toco como ogã convidado desde 2013.

Segundo relato cedido depois de uma "gira de direita", ${ }^{15}$ dona Alcina conta que a sua avó Maria Madalena Martins, conhecida como dona Polaca, que morava na cidade de Governador Celso Ramos e depois em Tijucas, desde os 12 anos de idade já atuava como benzedeira. Ela atendia muita gente de toda a região do Vale do Itajaí, tanto na sua casa, na sua sala, quanto na casa das pessoas, sendo que ela havia aprendido tudo sozinha.

Dona Alcina informa também que a sua avó faleceu há "30 anos", ${ }^{16}$ quando tinha "80 anos" de idade. Então, fazendo uma conta rápida, ela deveria ter hoje "110 anos", sendo, portanto, nascida em torno de "1910". Ou seja, perfazendo uma estimativa, lá para meados do início da década de 20 do século passado já havia práticas de benzedura na região de Tijucas, que fica situada entre Itajaí e Florianópolis, praticamente no meio dessas duas cidades.

Dona Alcina revela que a sua avó era espírita, mas, por conta do forte preconceito que a sociedade tinha com "essas coisas", ${ }^{17}$ tanto ela como tantas outras benzedeiras da região evitavam usar o termo espírita. Segundo dona Alcina, havia muitas benzedeiras na região de Tijucas, e todas elas atendiam pessoas de todas as classes sociais. Vale lembrar que, até a metade do século passado, as práticas ritualísticas afro-brasileiras, como o curandeirismo, eram consideradas crime (ORO, 2004, p.324). Ou seja, se havia a tentativa de proibir o trabalho de benzedeiras e de curandeiros, ${ }^{18}$ bem como de silenciar os atabaques ou qualquer outro tipo de tambor, é sinal de que havia a intenção de restringir as práticas de matriz africana, o que comprova a existência de manifestações

\footnotetext{
12 Para mais detalhes sobre a relação entre os casos de perturbações e mediunidade, ver Magnani (2002).

13 Conversa informal realizada no salão do terreiro antes de um ritual interno no dia 17/10/2018.

14 Conversa informal realizada no pátio externo do terreiro no dia 13/3/2020.

15 Na chamada Umbanda de Sete Linhas são realizados dois tipos de rituais. Na "gira de direita" são cultuados os "caboclos" (representantes simbólicos dos orixás) e "pretos velhos"; enquanto a "gira de esquerda" é voltada para os "exus" e "pombos-gira".

$16 \quad$ Números entre aspas significam quantidade aproximada.

17 Palavras ditas por dona Alcina.

18 Segundo o Pai Nino do Terreiro Capivari - Casa de Obaluayêe Oxumarê, em São Félix/BA, curandeiro designava os regentes espirituais na época dos escravos na região do Recôncavo Baiano; e que pai de santo, mãe de santo, babalorixá e ialorixá são termos criados mais recentemente. Conversa informal realizada na varanda do terreiro na manhã do dia 16/8/2019.
} 
afrorreligiosas desde a segunda metade do século XIX em Santa Catarina, incluindo Itajaí. Talvez ainda não sistematizadas ou pelo menos não organizadas com o nome de umbanda, candomblé ou outro termo correspondente. Diante do receio da repressão e do preconceito, as pessoas que tinham o lado espiritual desenvolvido não faziam menção ao termo espírita. Tal estigma perdurou até a década de 40 do século XX (TRAMONTE, 2001, p.13).

Essa postura terá reflexos mais tarde na escolha dos nomes dos terreiros de umbanda que surgiram a partir de 1940. Por exemplo, conforme aponta o mapeamento do Nuer (2017), muitas casas religiosas de matriz africana da Grande Florianópolis adotaram as seguintes designações: Associação Cultural e Religiosa, Associação Espírita, Casa de Caridade, Centro Espírita, Fraternidade Espírita, Instituto Espírita, Sociedade Beneficente, Sociedade Espírita, Tenda Espírita etc. (NUER, 2017, p.33).

\section{Do kardecismo à umbanda de 1940}

Entre o final do século XIX e o início do século XX, o espiritismo kardecista, depois de chegar ao Brasil pelos portos da Bahia, foi se difundindo pelo restante da federação com enorme sucesso (BASTIDE, 1971, p.432-435). D'Ávila (2018) informa que o Brasil é o único país em que os princípios fundados por Allan Kardec foram transformados em religião, porque a sua base doutrinal, filosófica e científica, que busca explicar a natureza da vida e da morte, acabou atraindo muitos brasileiros (D'ÁVILA, 2018, p.348).

Como vimos, nessa mesma época, no litoral de Santa Catarina, os trabalhos espirituais eram realizados individualmente por curandeiros e benzedeiras, evoluindo depois para pequenos grupos domésticos até a instalação dos centros espíritas (CONCONE, 1987; PRANDI, 2012; MARTINS, 2011). Por exemplo, no ano de 1895, é fundado o primeiro Centro Espírita Kardecista de Santa Catarina, na cidade de São Francisco do Sul (MARTINS, 2011, p.29). Em Itajaí, os primeiros grupos espíritas foram formados nas primeiras décadas do século $X X$, inicialmente compostos por trabalhadores urbanos, depois pela classe média e, posteriormente, por operários do porto (D'ÁVILA, 2018, p.348). Nessa direção, Rodrigues (2016) acrescenta que muitos negros buscaram se aproximar da doutrina kardecista porque esta tinha melhor aceitação na sociedade (RODRIGUES, 2016, p.8). Deve-se salientar que o Porto de Itajaí era justamente um dos locais em que os negros trabalhavam. Ou seja, podemos ter aqui algum indício do encontro das religiões afro-brasileiras com a doutrina kardecista. Portanto, uma das marcas desse período é o deslocamento do espiritismo do branco para o negro (BASTIDE, 1971, p.434).

Principalmente na Bahia e no Rio de Janeiro, "o kardecismo encontrou uma cultura bastante familiarizada com as ideias de transe como meio de comunicação com espíritos, de reencarnação e de cura espiritual, que foram assimiladas das religiões indígenas e africanas" (PRANDI, 2012, p.93). Conforme explica Bastide (1971), a assimilação do animismo, anteriormente praticado por grupos bantos e indígenas, foi fundamental para o desenvolvimento do espiritismo no Brasil, pois, por meio da justificação científica, abriu-se as portas para que as práticas religiosas dos negros fossem igualmente 
valorizadas (BASTIDE, 1971, p.434-435). A partir de então, muitas pessoas do candomblé baiano, banto e iorubá, bem como dos terreiros de macumba ${ }^{19}$ carioca, passaram a frequentar as casas kardecistas, compartilhando com estas algumas de suas práticas religiosas e entidades; porém o choque das concepções filosóficas e o preconceito aos cultos afro-brasileiros fizeram emergir, por volta do ano de 1920, no Rio de Janeiro, a umbanda como uma nova religião mediúnica (PRANDI, 2012, p.93-94; CONCONE, 1987, p.54-56). Para Bastide (1971), a "umbanda é uma valorização da macumba através do espiritismo" (BASTIDE, 1971, p.439).

Posteriormente, a umbanda se espalhou pelo território carioca, depois por São Paulo e, em seguida, por todo o país e em alguns países vizinhos (PRANDI, 2013, p.203). Segundo Bastide (1971), a expansão da umbanda foi favorecida pelas mudanças ocorridas nas classes mais baixas da sociedade, que estão associadas com o "desenvolvimento da escola, da instrução obrigatória, da mistura de raças nas fábricas e das necessidades novas nascidas com as transformações da estrutura social", porém o desejo de se manter vinculado à África foi uma estratégia para se opor ao mundo capital (BASTIDE, 1971, p.431).

Em Santa Catarina, nos primórdios da umbanda era muito comum proceder os atendimentos individuais nas próprias residências, como também reacomodar alguns móveis dos cômodos para realizar os rituais coletivos (NUER, 2017, p.86). Conforme afirma Martins (2011), até aproximadamente o ano de 1940, diversas práticas espiritualistas continuaram acontecendo de forma sigilosa e não institucionalizada, como as atividades religiosas similares e antecessoras da umbanda (MARTINS, 2011, p.29). Mas "toda tradição é mesmo inventada e reinventada (des)continuamente, e daí o papel dos indivíduos na construção das tradições" (BRAGA, 2003, p.126).

Segundo Tramonte (2001), a partir da década de 1940, as primeiras casas afrorreligiosas surgem de forma discreta nas periferias das cidades, dando continuidade aos trabalhos que eram feitos individualmente pelas benzedeiras e curandeiros, ao mesmo tempo que ampliavam o atendimento e as relações culturais com diversas classes sociais (TRAMONTE, 2001, p.17, 54). Em Itajaí, apesar de haver referências aos cultos africanos desde o século XIX, a institucionalização só aconteceu na segunda metade do século XX (D'ÁVILA, 2018, p.348).

Nesse percurso, brevemente exposto neste artigo, "a umbanda será a pioneira das religiões afro-brasileiras na região, abrindo caminho para o surgimento de outros rituais tais como: Almas e Angola [...]; Candomblé [...]; e outros como Omolocô e Cabula [...]" (TRAMONTE, 2011, p.73). Concordando com Laplantine: "[...] quanto mais uma sociedade tende a uniformizar-se, mais tende simultaneamente a diversificar-se" (LAPLANTINE, 2012, p.189).

Finalmente, a história das religiões de matriz africana em Santa Catarina terá o seu divisor de águas relacionado com a trajetória de vida de Mãe Malvina, considerada a primeira mãe de santo catarinense nascida em Itajaí, mas que abriu o seu terreiro de

19 Nome dado ao candomblé no Rio de Janeiro, quando era a capital brasileira (PRANDI, 2012, p.93). Para Cacciatore (1977), trata-se de um "termo genérico para os cultos afro-brasileiros derivados do nagô, mas modificados por influência angola-congo e ameríndias, católicas, espíritas e ocultistas que se desenvolveram, a princípio, no Rio de Janeiro" (CACCIATORE, 1977, p.166). 
umbanda em Florianópolis, o primeiro oficialmente registrado no estado.

Portanto, a região compreendida entre Joinville e Florianópolis teve um processo histórico-religioso diferente do que aconteceu na Bahia e no Rio de Janeiro, influenciado tanto pelas questões geográficas e econômicas como pelo projeto político de criar o "Vale Europeu"20 em Santa Catarina, que influenciou decididamente a proporção entre negros e brancos. Considerando também o preconceito, a invisibilidade e a repressão, podemos compreender por que, "ao contrário da trajetória dos negros baianos, os primeiros terreiros [catarinenses] de práticas religiosas afro-brasileiras serão de umbanda, e não de candomblé" (TRAMONTE, 2001, p.79).

\section{Mãe Malvina, do candomblé à umbanda}

O terreiro de Mãe Malvina, o Centro Espírita São Jorge Guerreiro, fundado em 1947 e registrado oficialmente em 1953, pelo pioneirismo e pela importância que adquiriu, é tido como o marco inicial da umbanda na região da Grande Florianópolis (TRAMONTE, 2001, p.51; NUER, 2017, p.103). Por conta disso, dona Malvina Ayroso de Barros, mulher negra que nasceu em 14/9/1910 na cidade de Itajaí, é considerada a primeira mãe de santo catarinense, contabilizando 47 anos de dedicação à religião umbandista (D'ÁVILA, 2018, p.351; NUER, 2017, p.80). Observa-se que a escolha da designação do nome oficial do terreiro foi uma maneira de superar o preconceito local.

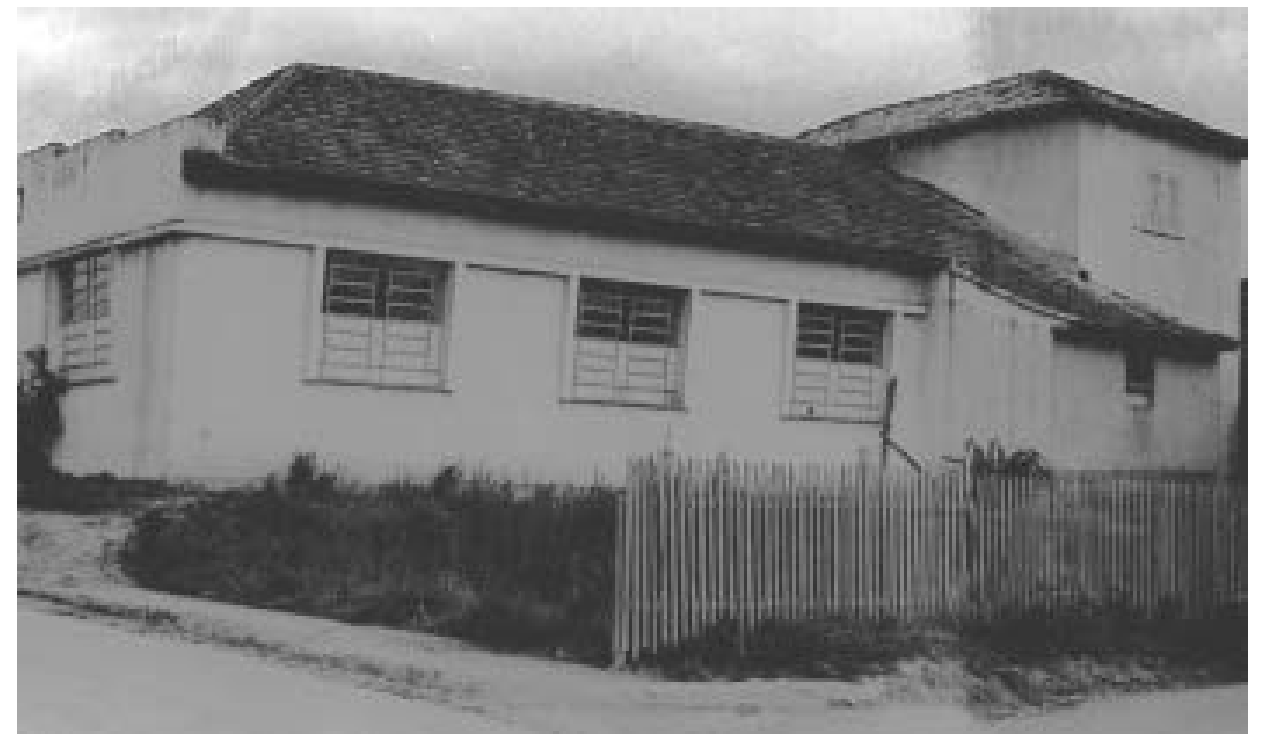

Fig. 2: Centro Espírita São Jorge Guerreiro. Fonte: Menêses (1973 apud NUER, 2017, p.81).

Mãe Malvina começou a sua trajetória de vida como tecelã e artesã, porém em torno dos 30 anos de idade começou a ter ataques epiléticos que continuaram com o passar dos anos, sendo curada somente após a sua iniciação na umbanda, apesar de ser católica (TRAMONTE, 2001, p.52). D'Ávila ${ }^{21}$ (2020) conta que a Mãe Malvina, itajaiense, foi casada primeiro com um marinheiro baiano, com quem acabou conhecendo e desenvolvendo

20 Conjunto de cidades de colonização europeia situado numa região entre montanhas e rios.

21 Conversa informal realizada no dia 1/3/2020 na sala de sua residência (D'ÁVILA, 2020). 
a sua afrorreligiosidade (D'ÁVILA, 2020). Lembramos que Itajaí é uma cidade portuária. Recebendo apoio do seu segundo marido José de Barros, que era umbandista, inicia-se efetivamente na umbanda, no ano de 1941, no Rio de Janeiro, onde recebe e desenvolve as entidades que trabalharia no futuro, em especial a Vovó Maria Conga de Angola, a regente do gongá do seu terreiro (MARTINS, 2011, p.29; TRAMONTE, 2001, p.52).

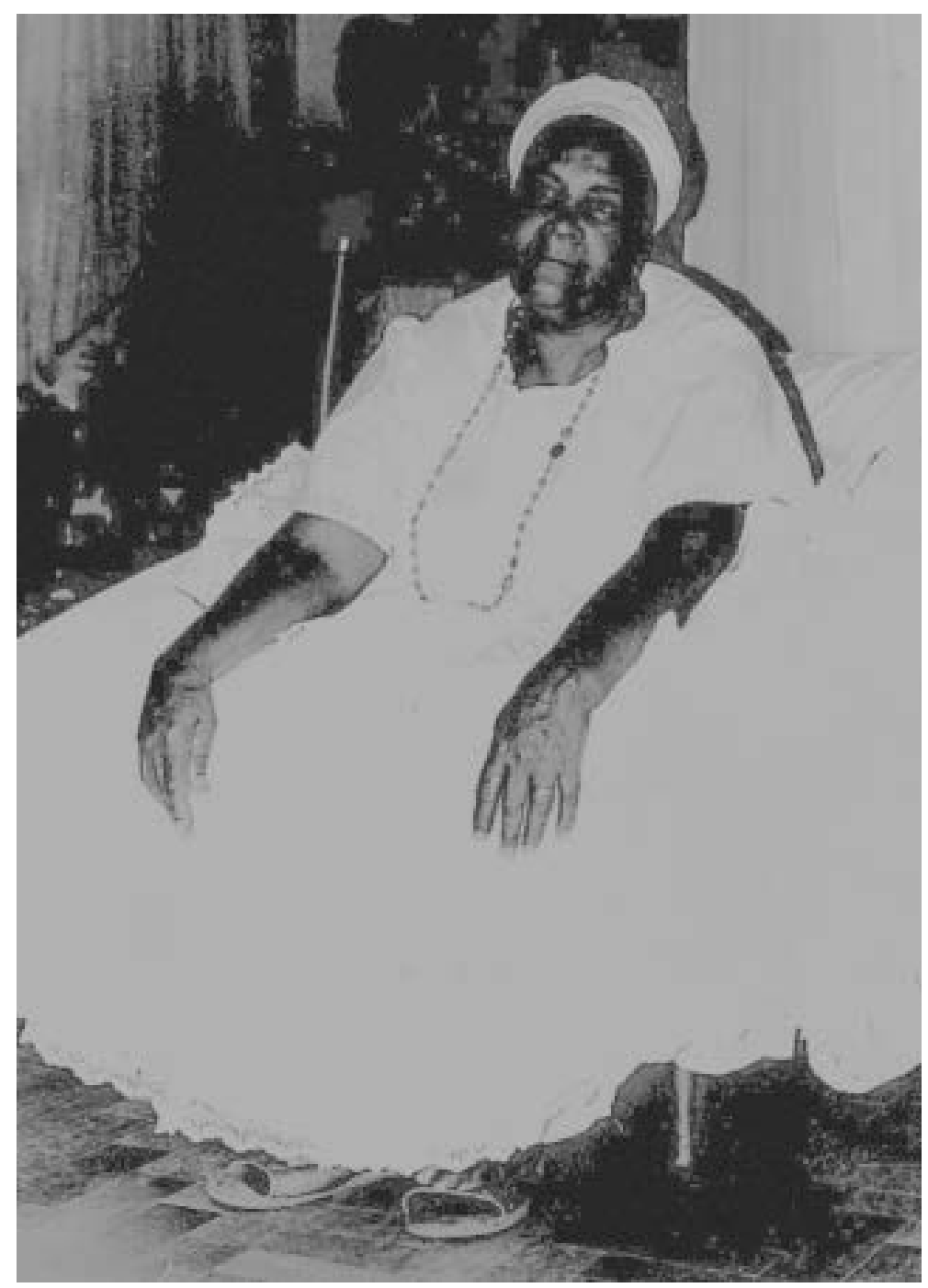

Fig. 3: Mãe Malvina. Fonte: MENÊSES (1973 apud NUER, 2017, p.80).

Posteriormente, durante uma viagem para Salvador, no dia 2/2/1946, considerado o dia de lemanjá, consagra-se como mãe de santo na escadaria da Igreja de Nosso Senhor do Bonfim; e no ano posterior, no dia 14/9/1947, inaugura o seu terreiro no bairro do Estreito, na época uma região afastada do centro de Florianópolis (MARTINS, 2011, p.29; TRAMONTE, 2001, p.52). D'Ávila (2020) informa que, nessa época, Itajaí era uma cidade pequena, provinciana e repleta de preconceitos às práticas afrorreligiosas. Como era muito difícil abrir e manter uma casa aberta em Itajaí, Mãe Malvina acabou se transferindo para Florianópolis (D'ÁVILA, 2020).

Segundo Tramonte (2001), existem relatos sobre a existência de reuniões de mé- 
diuns que aconteciam na região de Florianópolis antes da chegada de Mãe Malvina, porém os encontros, até então, eram realizados sem o uso de instrumentos de percussão, por conta do receio da repressão policial (TRAMONTE, 2001, p.53). Então, pelo que parece, a institucionalização do termo umbanda está relacionada com a inserção dos toques de atabaques trazidos pela Mãe Malvina. No entanto, essa é uma questão pouco explorada e que merece ser aprofundada em outra oportunidade.

Outra questão que surge está relacionada com a história de vida de Mãe Malvina em Itajaí antes de sua viagem para o Rio de Janeiro. Se ela começou a desenvolver a sua mediunidade influenciada pelo primeiro marido, que era baiano, eles deveriam praticar a espiritualidade em algum espaço; e se o segundo marido era umbandista, ele e ela deveriam frequentar algum lugar na região de Itajaí. Nessa direção, Silva (2016) acrescenta: "José de Barros já era umbandista quando aconselhou Malvina a entrar para a umbanda. A mesma notícia diz que José já havia fundado um terreiro no ano de 1945, mas em outra localidade" (SILVA, 2016, p.57). O fato é que esta "outra localidade" não é mencionada nos documentos, porém há fortes indícios de que seja Itajaí.

Para completar essa questão, é oportuno trazer dados da entrevista cedida por Pai Fabriciano ao jornal Diarinho de Itajaí (PAI..., 2008, p.1). Na época, Pai Fabriciano, nascido em Itajaí em 22/8/1929, tinha 79 anos e era o pai de santo mais velho em atividade em Santa Catarina, vindo a falecer em 2019 (PAI..., 2008, p.3). Nessa reportagem, ele conta que foi iniciado na umbanda pela Mãe Cecília, que, na época da entrevista, estava com 91 anos de idade. Então ela deve ter nascido em 1917 e portanto era contemporânea de Mãe Malvina. Além disso, se Mãe Cecília era mãe de santo de umbanda, podemos imaginar que ela fora iniciada por alguém, possivelmente por alguém de fora, e que talvez Mãe Malvina e José de Barros frequentassem a sua casa, embora ainda sem a formatação tradicional de um terreiro de umbanda atual.

Outros aspectos bastante relevantes da trajetória religiosa de Mãe Malvina, pouco pesquisada, mas que precisamos retomar e enfatizar, estão relacionados com o seu desenvolvimento espiritual, tanto no Rio de Janeiro quanto na Bahia. Segundo Tramonte (2001), na primeira viagem realizada ao Rio de Janeiro, Mãe Malvina desenvolveu as seguintes entidades: Vovó Maria Conga de Angola, Ogun Guerreiro, Caboclo Munhangaba e Cabocla Jurema. Abrindo um parêntese, desenvolver é um termo êmico que pressupõe uma certa iniciação anterior (TRAMONTE, 2001, p.52-53). Conforme Cacciatore (1977) todas estas entidades são cultuadas em cultos afro-brasileiros, como, por exemplo, a umbanda e o candomblé de caboclo.

Para ajudar a compreensão, acrescentamos uma explicação de Cacciatore (1977) sobre o candomblé de caboclo e a sua relação com a umbanda, bem como com o candomblé ketu, a religião dos orixás, como segue:

[O candomblé de caboclo é um] culto afro-brasileiro saído do candomblé tradicional baiano para atender às necessidades dos crentes de terem uma assistência direta das divindades às suas aflições cotidianas [...]. Algumas iaôs saíram de seus candomblés e fundaram as primeiras casas deste tipo de culto, onde as crenças e rituais nagô se uniram à pajelança, já misto de rituais bantos, europeus (espíritas e católicos-populares) e indígenas. A diferença principal é que 
os orixás (aí Encantados) não descem diretamente entre os homens, mas são representados por entidades caboclas (espíritos evoluídos de antepassados indígenas brasileiros). Os caboclos, representando os orixás ou a si próprios, falam, bebem, fumam e dão consultas aconselhando e receitando para os males dos crentes. [...] Posteriormente houve a adoção da Linha das Almas, recebendo espíritos evoluídos de antigos escravos (pretos velhos). Configura-se então um novo culto, fusão de várias influências, já brasileiro em sua formação: a umbanda. (CACCIATORE, 1977, p.79).

É oportuno registrar que esse tipo de comportamento das entidades do candomblé de caboclo pode ser visto hoje em dia no litoral catarinense nos terreiros de umbanda e nos terreiros de candomblé que também realizam giras e festas ${ }^{22}$ de umbanda, como, por exemplo, o Terreiro do Pai Jean, em Itajaí.

Retornando para a Bahia, há uma questão de extrema relevância: a relação de Mãe Malvina com Mãe Menininha. No trabalho realizado por Tramonte (2001), a dona Juraci Ayroso, "filha carnal" de Mãe Malvina, confirma que a sua mãe realizou a "feitura" como mãe de santo na escadaria da Igreja do Nosso Senhor do Bonfim, na data já mencionada aqui (TRAMONTE, 2001, p.52). Silva (2016), além de manter essa informação (SILVA, 2016, p.186), acrescenta que, ao entrevistar uma umbandista de Florianópolis com o nome de Graziela, esta relatou que a Mãe Malvina foi para Salvador para obter mais ensinamentos e fundamentos, e que a Mãe Menininha acabou "fazendo parte da sua cabeça"z3 (SILVA, 2016, p.65).

Sobre esse fato, apresento algumas observações. Segundo Silva (2016, p.139), "Vovó Maria Conga" era uma "preta velha", uma entidade que "zelava" pela Igreja do Nosso Senhor do Bonfim em Salvador (SILVA, 2016, p.139), o que pode justificar o local escolhido. No entanto, fica o questionamento da escolha de Mãe Malvina por "fazer a cabeça" com Mãe Menininha, ${ }^{24}$ uma das mães de santo de candomblé mais famosas do Brasil, bem como o porquê de o ritual ter acontecido fora do Terreiro do Gantois.

Uma das razões pode estar associada ao prestígio que o Gantois tinha na época. Segundo Castillo (2010), o terreiro de Mãe Menininha foi objeto de pesquisa de várias etnografias, que contribuíram para dar visibilidade junto à sociedade, legitimando as suas práticas religiosas como puras, antes vistas como de feitiçaria ou curandeirismo, bem como "houve uma reestruturação paralela nas relações de poder entre os terreiros", que colocaram o Gantois numa pequena elite (CASTILLO, 2010, p.17-18). Como sugere Lima (1976), a fama atribuída a alguns terreiros de candomblé ketu de Salvador tem mais relação com os etnólogos do que com os adeptos da religião (LIMA, 1976, p.74-75). Conforme aponta Silva (2016), esse vínculo espiritual estabelecido com Mãe

\footnotetext{
220 termo "gira" é mais utilizado para os rituais de caráter litúrgico e que possuem periodicidade definida. Por exemplo, alguns terreiros fazem rituais semanais, outros quinzenais, em dias fixos da semana. As festas são eventos realizados para celebrar as entidades mais importantes da umbanda de cada casa. Geralmente acontecem duas vezes por ano, aos sábados à noite.

23 "Fazer cabeça" ou "fazer o santo" é uma expressão êmica que significa: "iniciar-se, submeter-se a determinados rituais e aprendizados das "coisas de santo". Preparar ritualmente a cabeça para "receber" os orixás ou as entidades. Na umbanda, esse ritual é menos rigoroso do que no candomblé" (CACCIATORE, 1977, p.123).

24 Maria Escolástica da Conceição Nazareth, antiga ialorixá da casa de candomblé ketu llé Iyá Omi Àse İyámasé, mais conhecido como o Terreiro do Gantois, considerado como um dos mais antigos e tradicionais da Bahia.
} 
Menininha pode ter dado certa importância à formação religiosa de Mãe Malvina, o que acabou legitimando-a como a primeira mãe de santo de Santa Catarina (SILVA, 2016, p.66). Se, por um lado, ainda não sabemos quais são os detalhes dessa viagem para Salvador, um debate que ficará para outras pesquisas, por outro lado, essa informação aflorou as questões abaixo.

Se Mãe Menininha era mãe de santo de uma casa muito tradicional de candomblé ketu, por que Mãe Malvina não "fez o santo" dentro do Gantois? Por que foi dito que o ritual aconteceu na frente de uma igreja? Essa "feitura de santo" foi de candomblé ketu ou de umbanda? Poderia ser algum ritual de candomblé de caboclo? Além do candomblé ketu, será que Mãe Menininha conhecia os fundamentos de outra religião? ${ }^{25}$ Quais cantigas, toques, atabaques e outros instrumentos podem ter sido trazidos por Mãe Malvina para Santa Catarina? Deve-se salientar que não há o interesse de questionar a história oral, mas de realçar os vínculos estabelecidos entre Santa Catarina e a Bahia e da umbanda com o candomblé ketu.

Independentemente de o pioneirismo de Mãe Malvina ter sido ou não instituído por outras pessoas ao longo do tempo, o mais relevante nesse momento é o que o início da formação oficial da umbanda em Santa Catarina, em especial Florianópolis e Itajaí, está associado a um dos terreiros de candomblé ketu mais tradicionais e mais antigos de Salvador. Indo mais além, se o parentesco é uma linguagem (STRAUSS, 2017), essa relação religiosa embrionária entre Mãe Malvina e Mãe Menininha pode ajudar a explicar por que vários regentes espirituais da umbanda migraram para o candomblé ketu, bem como o fato de alguns babalorixás e ialorixás continuarem a realizar rituais de umbanda em seus terreiros de candomblé.

A respeito da mistura de doutrinas, "a própria mãe Malvina identificava a [sua] casa como sendo um centro de umbanda e de quimbanda" (NUER, 2017, p.79); enquanto hoje em dia na capital catarinense é perceptível a influência da origem africana na umbanda" (TRAMONTE, 2001, p.74). Acrescente-se, ainda, que essa "bricolagem de concepções e práticas religiosas" também foi percebida no Rio Grande do Sul, como fruto da "trajetória pessoal de cada um" e das realidades regionais (BRAGA, 2013, p.212).

Para finalizar essa seção, é oportuno deixar registrado o legado que Mãe Malvina deixou para a umbanda da sua terra natal. Conforme diversos relatos obtidos nas visitas aos terreiros, informações que são convergentes com o estudo de Rodrigues (2016), temos que, "do terreiro da Mãe Malvina, em Florianópolis, espalharam-se filhos de santo por todo o Vale do Itajaí" (RODRIGUES, 2016, p.9). Segundo Silva (2016) e D'Ávila (2018), o sr. Altamiro José Pereira (1938-2011), conhecido como Pai Altamiro, marido de Juraci, filha de sangue de Mãe Malvina, foi a pessoa responsável por disseminar a doutrina de Mãe Malvina e, por conta disso, é considerado o seu sucessor (SILVA, 2016, p. 58; D'ÁVILA, 2018, p. 351). 


\section{Da umbanda ao candomblé}

A partir da década de 1940, com mais ênfase na década seguinte, começa o desenvolvimento da umbanda no estado catarinense. O período entre 1940 e 1960 ficou marcado pela busca da quebra de preconceitos e pela afirmação religiosa, apesar da forte repressão policial (NUER, 2017, p.78-79, 87). É uma época onde aparecem os primeiros sinais da institucionalização das religiões afro-brasileiras em Santa Catarina (TRAMONTE, 2011, p.4).

Conforme aponta NUER (2017), o estabelecimento oficial dos primeiros terreiros acontece principalmente na região da capital, em Florianópolis; no litoral sul, em Criciúma, Laguna e Tubarão; e no litoral norte, em Itajaí e Joinville; locais estes onde a umbanda se tornaria "a forma ritual explícita pioneira para garantir os primeiros espaços públicos, tendo o sincretismo como a principal estratégia [...] para o crescimento e a abertura dos canais de expressão religiosa nas décadas seguintes" (NUER, 2017, p.78-79).

Então, muitas casas são abertas, como, por exemplo, a Tenda Espírita São Jerônimo de Mãe Ida, que viaja em 1949 ao Rio de Janeiro para se tornar mãe de santo e introduz na capital catarinense em 1951 a Umbanda de Almas e Angola (MARTINS, 2011, p.30); o Centro Espírita Irmão Octaviano Ribeiro, conhecido hoje como ABTURI - Casa Luz d'Omolu, fundado por Mãe Ana, em 1952; só para citar algumas; bem como surgem outras casas de cunho kardecista e de umbanda esotérica (NEAR, 2017, p.87).

Em Itajaí, a umbanda começa a crescer no final da década de 1950 por conta dos trabalhos realizados pelo Pai Altamiro (D'ÁVILA, 2018, p.351). D'Ávila (2018) acrescenta que um dos primeiros registros feitos pela imprensa local, extraída do jornal Itajaí, em 1949, intitulada "Macumba em Itajai", faz referência às reuniões de caráter ilícito, de cunho religioso, que aconteciam com batucada e cantoria em duas casas situadas na avenida João Pessoa (D'ÁVILA, 2018, p.350).

Em torno de 1960, tanto a umbanda quanto o candomblé passaram a se espalhar pelo Brasil, em especial nas maiores cidades, num processo com muitas adaptações religiosas, influenciadas pela realidade social e cultural de cada região (NUER, 2017, p.39). Segundo Bastide (1971), nessa época o país estava passando por um intenso processo de transformação, que facilitou principalmente a disseminação do "espiritismo de umbanda" (BASTIDE, 1971, p.417).

Em Santa Catarina, em pleno aumento da densidade populacional resultante da modernização e apesar da busca pela identidade europeizada por parte da sua grande maioria, as religiões afro-brasileiras conseguiram certa visibilidade em virtude do seu engajamento coletivo, da criação de organizações, da realização de eventos de pequeno e grande porte, bem como do apoio da mídia (NUER, 2017, p.81; TRAMONTE, 2001, p.4-5, 73-100). Como consequência, houve uma expansão territorial das casas religiosas de umbanda e das kardecistas, que abriram os caminhos para a chegada do candomblé na região.

Assim, no território catarinense, as décadas de 1960 e 1970 são marcadas pelo surgimento de diversas organizações religiosas, como a União da Umbanda em Santa Catarina, em 1962; o Superior Órgão de Umbanda do Estado de Santa Catarina, em 1974; a 
União Umbandista de Joinville, em 1975; e a União Municipal Umbandista de Blumenau, em 1977 (MARTINS, 2011, p.30). A década de 70 do século XX, além da visibilidade na mídia, foi um período de forte tensão com a igreja católica (MARTINS, 2011, p.30).

Por esses anos, como o kardecismo era uma prática mais bem-vista socialmente, muitos umbandistas empregaram o termo espírita para o nome de suas casas (NUER, 2017, p.36). Em Itajaí, "a primeira instituição religiosa afro-brasileira a registrar-se [...] [foi] a Sociedade Espírita Oghum Beira Mar à Santa Rita, fundada em 27 de setembro de 1964, [...] cujos estatutos foram publicados no Jornal do Povo em 20 de março de 1965" (D'ÁVILA, 2018, p.351).

Ainda na década de 1970, os primeiros terreiros de candomblé são abertos em Florianópolis. Segundo Tramonte (2001), no ano de 1976, o Pai Juca abre o Centro Espírita Caboclo Serra Negra, considerado o primeiro terreiro de candomblé de Santa Catarina (TRAMONTE, 2001, p.39). Mãe Lídia, que já havia trabalhado como benzedeira e tinha se iniciado posteriormente na Umbanda Omolocô, ${ }^{26}$ no ano de 1979 criou a Comunidade Terreiro Abassá de Odé, o primeiro terreiro de Nação Angola catarinense com "raiz"27 do Tumba Jussara, um dos terreiros mais antigos da Nação Angola de Salvador (NUER, 2017, p.85). Nota-se que a capital baiana continua sendo um vínculo importante para as religiões afro-brasileiras em Santa Catarina. Outro fato relevante em relação à década de 70 do século XX é a migração de comunidades indígenas de base guarani, originárias do sul do país, que se estabeleceram na cidade de Biguaçu, a poucos quilômetros da capital (NUER, 2017, p.52).

No que se refere às datas de criação das casas religiosas na Grande Florianópolis, conforme mostra o Quadro 1, é possível observar um salto quantitativo a partir da década de 80 do século XX, com destaque para o período entre os anos de 2000 e 2010. Não temos dados dessa natureza sobre Joinville e Itajaí, mas por conta das ressonâncias históricas, acredita-se que tenha havido um cenário proporcionalmente parecido.

PERÍODO DE FUNDAÇÃO DAS CASAS DE RELIGIÃO DE MATRIZ AFRICANA DA GRANDE FLORIANÓPOLIS ATÉ DIA 15/01/2017:

\begin{tabular}{|c|c|}
\hline Período de Fundação & No de casas \\
\hline $1950-1980$ & 17 casas \\
\hline $1981-1999$ & 55 casas \\
\hline $2000-2010$ & 74 casas \\
\hline $2011-2016$ & 50 casas \\
\hline Não declarado & 14 casas \\
\hline Total: & 210 casas \\
\hline
\end{tabular}

Fonte: Projeto Territórios do Axé. 2016/2017 (Convênio IPHAN/NUER-UFSC)

Quadro 1: Período de fundação dos terreiros na Grande Florianópolis. Fonte: Nuer (2017, p.84).

26 "Culto cuja linha ritual é originária da nação angola, mais particularmente, talvez, das tribos lunda-quiôco. Sobressaiu especialmente no Rio de Janeiro, ligado à umbanda" (CACCIATORE, 1977, p.193).

27 Descendente, que adota os mesmos princípios religiosos. 
No caso de Joinville, conforme aponta Machado (2012), entre os anos de 1960 e 1980, a cidade passou por um processo de crescimento industrial que fomentou uma intensa migração regional (Sul e Sudeste) e aumento da população local, alterando assim o cenário ${ }^{28}$ das práticas afrorreligiosas (MACHADO, 2012, p.22-23, 46). Segundo o historiador, se até 1980 só havia terreiros de umbanda em Joinville, a partir da virada da década, surgem na cidade os primeiros terreiros de candomblé, que enfrentaram muitas dificuldades para se manterem (MACHADO, 2014, p.25).

Na sequência, na década de 1980, na região da Grande Florianópolis, em paralelo à expansão afrorreligiosa, as migrações continuaram acontecendo, desta vez com a chegada dos trabalhadores rurais do planalto serrano catarinense e de descendentes de alemães e italianos que vieram do oeste catarinense e do estado do Rio Grande do Sul (NUER, 2017, p.52). Em Itajaí "a presença do candomblé é mais restrita e recente [...], sendo notada a partir dos anos 1980 e 1990" (D'ÁVILA, 2018, p.351).

A partir da década de 1990, acentua-se uma nova fase, caracterizada pela busca de novos caminhos para a afrorreligiosidade em Santa Catarina, o que pode estar vinculado à abertura de mais casas de candomblé, muitas das quais surgidas por conta da migração religiosa de muitos regentes espirituais da umbanda para o candomblé ketu. Por outro lado, essa tendência de mudar de religião já tinha acontecido em 1982, quando Mãe Dilma d'lemanjá Ogunté muda o ritual da sua casa de umbanda para Almas e Angola (NUER, 2017, p.88).

Portanto, forma-se nessa região uma espécie de "hibridismo doutrinal" constituído a partir da "dupla descendência de santos" (NUER, 2017, p.107). Conforme aponta García Canclini (2015), a hibridização pode ser caracterizada por meio de três processos fundamentais: "[...] a quebra e a mescla das coleções organizadas pelos sistemas culturais, a desterritorialização dos processos simbólicos e a expansão dos gêneros impuros; que pode ser intensificada pela expansão urbana (GARCÍA CANCLINI, 2015, p.284-285).

Nesse contexto, muitos terreiros de umbanda foram transformados em terreiros de candomblé ketu, porém, além do calendário, rituais e atividades específicos aos orixás africanos, estes centros ainda mantêm certos ritos, festas e homenagens às entidades da umbanda. Destes, é oportuno destacar alguns que foram visitados durante o trabalho de campo, ${ }^{29}$ a saber: Ilê Alaketú Oyá Onìrá Asé, do Pai Jean, em Itajaí; Ilê-Asé Yemonjá Ygbô, de Mãe Emília, em Porto Belo; Ilê Alaketu Ase Odo Alasan, de Mãe Eve-

\footnotetext{
28 Para ilustrar essa mudança de cenário ocorrido em Joinville, apresentamos alguns dados extraídos da pesquisa de Machado (2012). Em 1979, Pai Fernando de Oxóssi, vindo de Jaraguá do Sul, abriu um terreiro de umbanda e alguns anos depois passou a trabalhar também com candomblé ketu (p.110-114); em 1982, Mãe Marli de Iyemanjá Ogunté inaugurou o primeiro terreiro de candomblé ketu, o llê Axé de lyemanjá Ogunté (p.135); em 1986, Pai Chiquinho de Oxóssi, nascido na Bahia, montou um terreiro de umbanda e candomblé de Angola (p.88-90); e Mãe Jacila de Oxum, vinda do Rio de Janeiro com iniciação na umbanda e candomblé ketu, atende na sua casa desde 1994 (p.97-98). E ainda temos Pai Jorge de Xangô, vindo de Itajaí, com um terreiro de umbanda e candomblé de Angola (p.95-97); o babalorixá Arildo de Zazi, de Joinville, com casa aberta de candomblé Angola (p.91-94); o babalorixá M. de Oxóssi e sua esposa C. de lyemanjá, naturais do estado de São Paulo, com terreiro de umbanda e candomblé ketu (p.71-73); e Mãe Kita de Oyá, nascida no Rio de Janeiro, iniciou-se no candomblé ketu no terreiro da Casa Branca em Salvador, migrando depois para o candomblé efon, a nação que comanda o seu espaço religioso (p.115-117); todos estes últimos sem data precisa de abertura das suas casas.
}

29 Entre abril de 2017 e julho de 2020, foram realizadas e catalogadas aproximadamente duzentas visitas de campo aos terreiros situados entre Itajaí e Florianópolis, contemplando diversos tipos de rituais, abertos e fechados ao público, festas, entrevistas, ensaios, aulas, oficinas de percussão, grupos de estudos, gravações dos ritmos etc. 
lise, em Penha; e Ilê Alaketu Okê Obá Ketu, de Pai Ricardo; e Ilê Asé Omim Babá Oxaguian, do Pai Edenilson, ambos em São José.

Nos terreiros citados acima, os rituais de umbanda e candomblé ketu possuem uma organização diferente e, consequentemente, isso se reflete na música. Em termos musicais, os repertórios, língua das cantigas, ritmos, forma de tocar os tambores, bem como a maneira de participação, são todos distintos. Na umbanda, geralmente o repertório é mais flexível, sendo composto por cantigas preferencialmente em português, não há uma sequência fixa, há mais liberdade na participação dos cantores e é permitida a inserção de novas composições. No candomblé ketu, o repertório de cantigas na língua iorubá tem um caráter mais rígido, canta-se apenas o que foi aprendido com os mais "velhos" e há pessoas iniciadas para esta função.

Voltando-se para a percussão, na umbanda os atabaques são percutidos com as mãos, possuem uma afinação mais alta, há poucos ritmos e as variações rítmicas não são exclusivas de um tambor. No candomblé ketu, os atabaques são tocados predominantemente com varetas naturais chamadas de aguidavis, há uma grande variedade de ritmos e os "solos" são tocados somente pelo atabaque mais grave. Uma questão importante é que a performance da percussão do candomblé ketu está diretamente associada às narrativas mitológicas expressas tanto nas letras das cantigas quanto nos gestos da dança dos orixás. Outro aspecto relevante diz respeito à quantidade de atabaques. Nestes terreiros que praticam as duas religiões, em todos os rituais são utilizados a formação tradicional oriunda do candomblé ketu, que é formada por três atabaques de afinação diferente, a saber: lé (agudo), rumpi (médio) e rum (grave). Por outro lado, nos terreiros apenas de umbanda, a quantidade de atabaques é variável, podendo ter entre um e seis atabaques.

Essa dinâmica de "coexistência religiosa de matriz africana" torna o panorama catarinense ainda mais diverso e complexo (NUER, 2017, p.44-45). Além disso, contando com o fato de que a "comunidade de santo"30 seja formada em sua maioria por "brancos", talvez seja possível especular que o perfil das religiões afro-brasileiras em Santa Catarina reflete a identidade cultural dessa parte do território nacional. Além disso, podemos adicionar a importância da figura do "caboclo" e de sua crença polissincrética. Segundo Lody (1977), "a imagem do indígena, nativo da terra, também significando mestiçagem entre branco e índio, mestiço que mora no mato, mulato de cabelo liso", "o caçador liberto", o "defensor da terra", "que não se deixou escravizar", carrega consigo práticas que evidenciam o sincretismo religioso entre os símbolos católicos e os elementos da tradição africana, que o tornam uma espécie de semideus cultuado em diversos tipos de terreiros para amenizar a vida dos humanos (LODY, 1977, p.3-8).

Do ponto de vista sociológico, Bastide (1971) explica que, por meio do mito do índio, a figura do caboclo foi utilizada de maneira inconsciente pelos negros, como uma forma de valorização espírita, mas também de aceitação social, ao "identificar-se com o herói da liberdade", tornando-se "um intérprete da valentia e do orgulho nativo" (BASTIDE, 1971, p.345-347). Conforme sugere Tramonte (2001), o elemento indígena pode 
ser a explicação dessa simbiose espiritual, pois, ao mesmo tempo que se aproxima das benzedeiras, sua feição, ervas, colares e outras características também se apresentam na umbanda e no candomblé de caboclo (TRAMONTE, 2001, p.31).

Outra questão que pode estar relacionada a esse panorama é o mercado religioso. Considerando que "as práticas culturais são mais que ações, atuações" (GARCíA CANCLINI, 2015, p.350), é possivel que a busca por mais poder esteja nas razões desse hibridismo. Ou seja, se o saber religioso constitui a base do capital simbólico e autoridade (CASTILLO, 2010, p.36), impulsionados pelo consumo religioso e pela "privatização da experiência religiosa" (ORO, 1997, p.42-43), muitos regentes espirituais voltaram-se para uma formação plural.

Independentemente desse "hibridismo doutrinal", na região do litoral catarinense entre Florianópolis e Joinville, na qual está situada a cidade de Itajaí, encontramos um cenário afrorreligioso do candomblé ketu diferente das casas mais tradicionais de Salvador. O desafio futuro será averiguar como essa dupla "descendência de santos", em casos de tripla, reflete nos padrões musicais, em especial no toque dos atabaques. Outra possibilidade é verificar qual a natureza do candomblé ketu no Brasil Meridional. O caminho pode estar na articulação com a fonte espiritual.

\section{Articulação com a fonte espiritual}

Em relação à articulação com a fonte espiritual, ou seja, o vínculo estabelecido com os sacerdotes mais experientes, no livro Territórios de Axé (NUER, 2017) são citados vários casos de pais e mães de santo residentes na Grande Florianópolis que iniciaram a sua trajetória religiosa com pessoas de outros estados, inclusive, em alguns casos, com iniciações religiosas em matrizes diferentes (NUER, 2017, p.105).

Nesse sentido e se direcionando para o candomblé, embora haja exemplos de regentes espirituais que se vincularam diretamente a fontes baianas, como é o caso do Pai Edenilson com a Mãe Senhora de Ewá (filha de santo de Mãe Menininha do Gantois), Pai Ricardo de Oxossi com Babá Pecê da Casa de Oxumarê, e mais recentemente Mãe Evelise, também com Babá Pecê; a maioria dos babalorixás e ialorixás com quem tive contato foram iniciados por mães ou pais de santo com terreiros abertos no estado de São Paulo ou Rio de Janeiro, que, por sua vez, tiveram suas iniciações religiosas vinculadas aos terreiros mais tradicionais de Salvador. Lembramos que a história de Mãe Malvina passa pelas cidades do Rio de Janeiro e de Salvador.

Alinhando-se às conclusões dos estudos feitos pelo Nuer (2017), foi constatado que, por meio das trajetórias sucessivas dos regentes espirituais e do processo verticalizado das linhagens das famílias de santo, é possível chegar direta ou indiretamente de Santa Catarina à Bahia do século XIX (NUER, 2017, p.105). Por exemplo, esse é o caso do babalorixá Jean Ty Onirá, o Pai Jean, que é filho de santo do Pai Sérgio de Oxum, de São Paulo, que é filho de santo do Pai Omoxalá, também de São Paulo, que é filho de Mãe Cacho, de Muritiba (BA), que é filha de Pai Nezinho de Muritiba, também Muritiba (BA), que por sua vez era filho de santo de Mãe Menininha do Gantois, Salvador. 
Durante a realização dessa pesquisa, conheci o Pai Sérgio de Oxum durante a realização da festa de candomblé para Oya Onirá em dezembro de 2018 e 2019, no terreiro do Pai Jean, em Itajaí; e, por conta da Festa da Irmandade da Boa Morte, na cidade de Cachoeira, No Recôncavo Baiano, foi possível ter uma conversa com Mãe Cacho em seu terreiro, na cidade vizinha, Muritiba. Durante a entrevista, Mãe Cacho relatou que Mãe Menininha passava muitos dias lá e inclusive mostrou o quarto ${ }^{31}$ em que se hospedava.

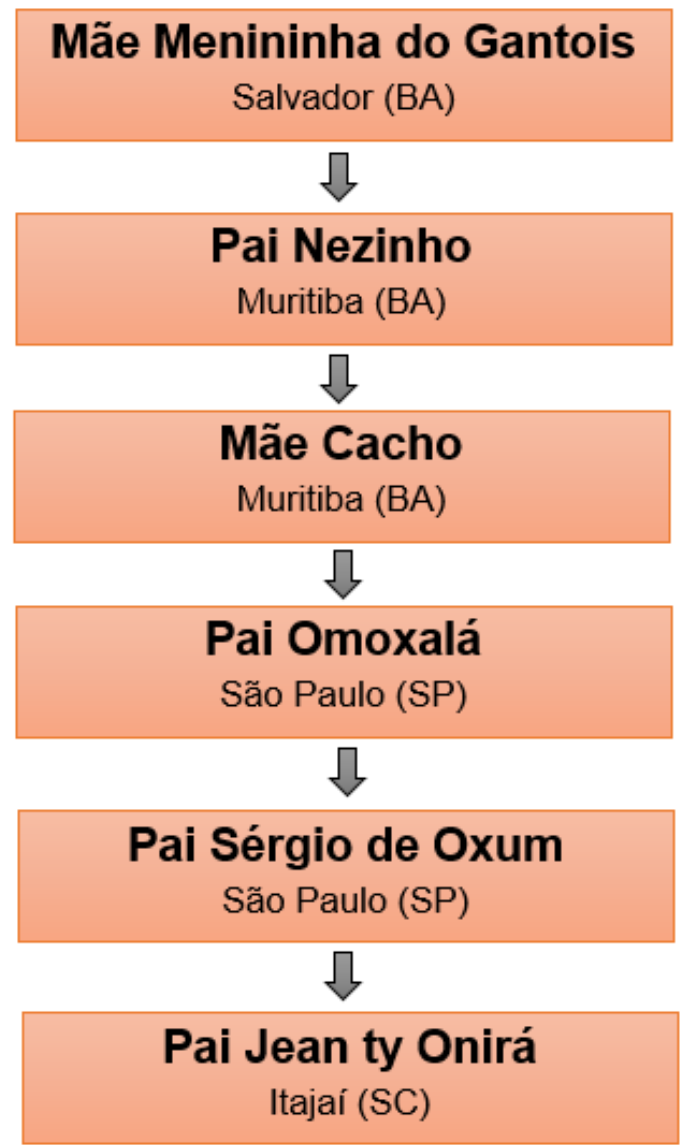

Fig. 4. Genealogia da família de santo do Pai Jean. Fonte: o autor (2019).

Conforme a Fig. 4, em termos de família religiosa, podemos concluir que, numa descida vertical, o Pai Jean faz parte da quinta geração pós-Mãe Menininha. Em termos equivalentes, Mãe Menininha seria a tataravó de santo de Pai Jean, e Mãe Cacho, a sua bisavó de santo. No entanto, embora a proximidade de categoria familiar entre Mãe Cacho e Pai Jean, soube que o contato entre eles é muito raro, tanto é que ela não se lembrava dele quando perguntei. Isso pode ser explicado pela distância geográfica ou também pela quantidade de filhos de santo iniciados por Mãe Cacho, que pode constituir uma gigantesca árvore genealógica.

Por conta disso, constatei que, no caso do Pai Jean, quando há necessidade de uma orientação religiosa, de qualquer espécie, ela é sempre feita diretamente com o 
seu pai de santo. Portanto, as práticas rituais realizadas no seu terreiro são mais parecidas com as do terreiro do Pai Sérgio do que com as do terreiro da Mãe Cacho, conforme disse o próprio Pai Jean, mas também frisando que algumas mudanças são possíveis, pois as pessoas são diferentes, as comunidades religiosas não são iguais, assim como as necessidades e a realidade da cada local. Então, embora o terreiro do Pai Jean tenha uma linhagem matricial vinculada ao Terreiro do Gantois, via Mãe Menininha, isso não quer dizer que os rituais e os calendários sejam iguais - e não são, como pude presenciar tanto em Itajaí quanto em Salvador.

Sendo assim, as famílias de santo formadas pelo desenvolvimento unidirecional das linhagens religiosas, ao mesmo tempo que procuram manter um conjunto de crenças e de tradições constituído ao longo do tempo, permitem também certos tipos de adequações locais, sem deixar de manter os mais novatos articulados com a fonte espiritual primária. Em Santa Catarina, a maioria dos terreiros está vinculada aos regentes espirituais do Rio de Janeiro e de São Paulo, com alguns casos ligados diretamente à Bahia.

\section{Considerações finais}

Como resultado desse estudo historiográfico, do ponto de vista religioso, percebe-se que a formação do candomblé na região catarinense compreendida entre as cidades de Florianópolis e Joinville está intimamente relacionada com a trajetória da umbanda, que, por sua vez, tem ligação com as práticas espirituais kardecistas, com a figura do caboclo indígena, bem como com as benzedeiras e com o curandeirismo dos antigos escravos e seus descendentes.

Se o processo de formação das religiões afro-brasileiras em Santa Catarina tem o seu ponto inicial marcado pela chegada dos negros escravizados, verificamos que, por conta da situação geográfica e das motivações político-econômicas da época, essa é uma região brasileira que ficou com pouca quantidade de negros, se comparada a outros estados da federação. Porém, voltamos a frisar que não se trata de ausência, mas de não querer ver e falar, fato comprovado pelo preconceito, pela repressão e pela escassez de pesquisas. No entanto, apesar da invisibilidade da história religiosa dos negros, percebe-se a existência de uma rede de conexões diaspóricas exercida em diferentes esferas pela comunidade dos terreiros há várias décadas.

Dentre as marcas mais relevantes a respeito dessa pequena história das religiões afro-brasileiras em Santa Catarina, fica registrado como destaque o trabalho árduo dos homens e mulheres negras que foram levados para esta região, a insistência dos curandeiros e benzedeiras pela cura das pessoas, o estabelecimento das irmandades negras, as manifestações culturais, bem como a existência dos portos regionais, que ajudaram os processos migratórios e favoreceram a "misturas das águas".

Do ponto de vista estrutural, a história afrorreligiosa catarinense inicia com as práticas individuais das benzedeiras e curandeiros. Na sequência, temos a formação de agrupamentos sociais, seja pela fundação das irmandades negras ou pelos pequenos grupos domésticos de benzedeiras e curandeiros que darão início à formação da umbanda. Em 
seguida acontece a instalação dos primeiros centros espíritas de doutrina kardecista e a aproximação por parte dos negros por conta da aceitação social. A partir daí surgem as primeiras casas de umbanda nas periferias das cidades e a busca pela institucionalização. Acompanhando o crescimento da população local, as casas de umbanda e as de doutrina kardecista ampliam em quantidade e expansão territorial, abrindo os caminhos para o candomblé. Tendo em vista a repressão religiosa e o preconceito, e pelo fato de o kardecismo ser mais aceito socialmente, muitos terreiros de umbanda foram fundados como casas espíritas. Logo após, surgem os primeiros terreiros de candomblé, de várias nações, como resultado da migração religiosa de muitos regentes espirituais oriundos da umbanda, que passam a praticar as duas modalidades de rituais no mesmo terreiro, porém com organização distinta, incluindo calendário, repertório, língua ritual, ritmos, danças, indumentárias e outros aspectos.

Nesse processo de formação das religiões afro-brasileiras, somam-se as trajetórias individuais de todos os catarinenses e residentes que fizeram ou fazem parte da comunidade de santo, independentemente das suas escolhas religiosas, dos caminhos percorridos e, principalmente, da cor da pele. Sabemos da importância de todos os pais e mães de santo, cada qual com as suas contribuições, porém aqui Mãe Malvina recebeu um destaque especial, por conta da existência de trabalhos acadêmicos sobre ela e pelo mito do marco fundador. Por conta disso, acreditamos que enfatizar a sua trajetória seria uma das maneiras de entender o atual panorama catarinense.

Ao realizar essa investigação histórica, diversos fatos foram descobertos e juntados, fazendo emergir uma série de questões, apresentadas anteriormente, das quais algumas serão futuramente respondidas. De imediato, como resultado dessa estratégia de ressonâncias, percebe-se que no estado de Santa Catarina, em especial no Vale do Itajaí, existem terreiros de candomblé ketu que apresentam uma dinâmica cotidiana diferente das casas matrizes de Salvador. Vimos que, na maioria dos casos, os laços religiosos perpassam os estados do Rio de Janeiro e de São Paulo para se chegar à Bahia. Além disso, a liberdade religiosa praticada nas diferentes matrizes espíritas, principalmente entre a umbanda e o candomblé ketu, criou na região um panorama caracterizado pelo hibridismo doutrinal.

\section{Referências}

ALVES, Jucélia Maria. Cacumbi: um aspecto da cultura negra em Santa Catarina. Florianópolis: UFSC, Secretaria da Cultura e do Esporte de Santa Catarina, 1990.

AMORIM, Tade-Ane. Benze, é bem dizer. As benzedeiras de Florianópolis: inventariando saberes. Florianópolis: Projeto via Edital Elisabeth Anderle, 2018.

BLACKING, John. How musical is man? 5. ed. Seattle; London: University of Washington, 1995 [6. ed.: 2000]. 
BLACKING, John. Que tán musical es el hombre? Desacatos, n. 12, p. 149-162, 2003. Trad. Briggite Sanabria. Texto original: BLACKING, John. How musical is man? 5. ed. Seattle; London: University of Washington, 1995.

BASTIDE, Roger. As religiões africanas no Brasil. São Paulo: Pioneira, 1971.

BRAGA, Reginaldo Gil. Tamboreiros de Nação: música e modernidade religiosa no extremo sul do Brasil. Porto Alegre: Ed. UFRGS, 2013.

BRAGA, Reginaldo Gil. Batuque Jêje-ljexá em Porto Alegre: a música no culto aos orixás. Dissertação (Mestrado em Música) - UFBA, Salvador, 1997.

BRAGA, Reginaldo Gil. Música e Modernidade religiosa entre tamboreiros de Nação: em torno de uma tradição musical moderna. Em Pauta, v. 14, n. 23, p. 121-141, 2003.

CACCIATORE, Olga Gudolle. Dicionário de cultos afro-brasileiros. 2. ed. Rio de Janeiro: Forense Universitária, 1977.

CANDEMIL, Luciano; PAIVA, Rodrigo Gudin. Percussão Catarina. Balneário Camboriú: Ed. do Autor, 2016.

CASTILLO, Lisa Earl. Entre a oralidade e a escrita: a etnografia nos Candomblés da Bahia. Salvador: UFBA, 2010.

COSTA, Moacir da; SILVA, José Bento Rosa da. Negros em Itajahy: da invisibilidade à visibilidade. Mais de 150 anos de história. Itajaí: Casa Aberta, 2010.

COSTA, Moacir da. Negras tradições: a Festa do Rosário e suas reinvenções. In: COSTA, Moacir da; SILVA, José Bento Rosa da. Negros em Itajahy: da invisibilidade à visibilidade. Mais de 150 anos de história. Itajaí: Casa Aberta, 2010. p. 13-44.

DA SILVA SELAU, Mauricio. História oral: uma metodologia para o trabalho com fontes orais. Esboços: histórias em contextos globais, v. 11, n. 11, p. 217-228, 2004.

D’ÁVILA, Edison. Pequena história de Itajaí. 2. ed. rev. ampl. Florianópolis: IHGSC, 2018.

D’ÁVILA, Edison. Pequena história de Itajaí. Itajaí: Prefeitura Municipal de Itajaí, 1982.

GARCÍA CANCLINI, Néstor. Culturas híbridas: estratégias para entrar e sair da modernidade. Trad. Heloísa Pezza Cintrão e Ana Regina Lessa. São Paulo: Ed. USP, 2015. 
GILROY, Paul. O Atlântico negro: modernidade e dupla consciência. Trad. Cid Knipel Moreira. 2. ed. São Paulo: Editora 34; Rio de Janeiro: Universidade Candido Mendes, Centro de Estudos Afro-Asiáticos, 2012.

HALL, Stuart. Da diáspora: identidades e mediações culturais. Belo Horizonte: Ed. UFMG; Brasília: Representação da Unesco no Brasil, 2003.

IBGE. Santa Catarina: Itajaí - Panorama. Brasília: IBGE, 2020. Disponível em: https:// cidades.ibge. gov.br/brasil/sc/itajai/panorama. Acesso em: 11 mar. 2020.

ITAJAÍ. Itajaí, entre o rio e o mar. Itajaí: Prefeitura Municipal de Itajaí, 2020. Disponível em: https://itajai.sc.gov.br/c/a-cidade\#.XmkXbqhKjIU. Acesso em: 11 mar. 2020.

LAPLANTINE, François. Aprender Antropologia. Trad. Marie-Agnès Chauvel. São Paulo: Brasiliense, 2012.

LEITE, Ilka Boaventura; OLIVEN, Ruben George. Negros no Sul do Brasil: invisibilidade e territorialidade. Florianópolis: Letras Contemporâneas, 1996.

LEITE, Ilka Boaventura. Descendentes de africanos em Santa Catarina: invisibilidade histórica e segregação. In: LEITE, Ilka Boaventura; OLIVEN, Ruben George. Negros no Sul do Brasil: invisibilidade e territorialidade. Florianópolis: Letras Contemporâneas, 1996. p. 33-53.

LEITE, Ilka Boaventura (coord.). Territórios do Axé: religiões de matriz africana em Florianópolis e municípios vizinhos. Florianópolis: Nuer; Ed. UFSC, 2017.

LÉVI-STRAUSS, Claude. Antropologia estrutural: Claude Lévi-Strauss. Trad. Beatriz Perrone-Moisés. São Paulo: Ubu, 2017.

LIMA, Vivaldo da Costa. O Conceito de "Nação" nos candomblés da Bahia. Revista Afro-Ásia, Salvador, Centro de Estudos Afro-Orientais (CEAO), n. 12, p. 65-90, 1976.

LODY, Raul. Samba de caboclo. Rio de Janeiro: Campanha de Defesa do Folclore Brasileiro, 1977.

MACHADO, Gerson. Os atabaques da Manchester: subjetividades, trajetórias e identidades religiosas afro-brasileiras em Joinville/SC (Décadas de 1980-2000). Tese (Doutorado em História) - Universidade Federal de Santa Catarina, Florianópolis, 2012.

MAGNANI, José Guilherme C. Doença mental e cura na Umbanda. Revista PPG Ciências Sociais, São Carlos: UFSC, n. 40/41, jan./jul. 2002. 
MAPASBLOG. Mapa dos municípios de Santa Catarina. Disponível em: http:// mapasblog. blogspot.com.br/2011/10/mapas-de-santa-catarina.html. Acesso em: 2 abr. 2017.

MERRIAM, Alan P. The anthropology of music. Evanston: Northwestern University Press, 1964.

OLIVEN, Ruben George. A invisibilidade social e simbólica do negro no Rio Grande do Sul. In: LEITE, Ilka Boaventura; OLIVEN, Ruben George. Negros no Sul do Brasil: invisibilidade e territorialidade. Florianópolis: Letras Contemporâneas, 1996. p. 13-32.

ORO, Ari Pedro. Os negros e os cultos afro-brasileiros no Rio Grande do Sul. In: LEITE, Ilka Boaventura; OLIVEN, Ruben George. Negros no Sul do Brasil: invisibilidade e territorialidade. Florianópolis: Letras Contemporâneas, 1996. p. 147-157.

ORO, Ari Pedro. Religiões afro-brasileiras do Rio Grande do Sul: Passado e Presente. Estudos Afro-Asiáticos, ano 24, n. 2, p. 345-384, 2002.

ORO, Ari Pedro. Notas sobre a diversidade e a liberdade religiosa no Brasil atual. Revista Eclesiástica Brasileira, v. 64, n. 254, p. 317-336, 2004.

ORO, Ari Pedro. Modernas Formas de Crer. Revista Eclesiástica Brasileira, Petrópolis, Vozes, n. 225, p. 39-56, mar. 1997.

ORTIZ, R. A morte branca do feiticeiro negro: umbanda e sociedade brasileira. 2. ed. São Paulo: Brasiliense, 1999.

PAI Fabriciano. Diarinho, Itajaí, 16 e 17 fev. 2008. Caderno Entrevistão.

PEDRO, Joana Maria. Negro em terra de branco: escravidão e preconceito em Santa Catarina no século XIX. Porto Alegre: Mercado Aberto, 1988.

PRANDI, Reginaldo. As religiões afro-brasileiras em ascensão e declínio. In: TEIXEIRA, Faustino; MENEZES, Renata (org.). Religiões em movimento: o censo de 2010. Petrópolis: Vozes, 2013. p. 203-218.

PRANDI, Reginaldo. Os mortos e os vivos: uma introdução ao espiritismo. São Paulo: Três Estrelas, 2012.

RASCKE, Karla Leandro. Festas, procissões e celebração da morte na Irmandade de Nossa Senhora do Rosário e São Benedito dos Homens Pretos m Desterro/SC (18601890). Itajaí: Casa Aberta, 2010. 
RASCKE, Karla Leandro. Irmandades Negras: memórias da diáspora no sul do Brasil. Curitiba: Appris, 2016.

RODRIGUES, Daniel Vasconcelos. Memória de santo: 15 anos de trajetória do terreiro de umbanda "junco verde" em Itajaí-SC. REDIVI: Revista de divulgação interdisciplinar virtual do núcleo das licenciaturas, v. 4, n. 1, 2016.

SEEGER, Anthony. Etnografia da música. Trad. Giovanni Cirino. Cadernos de campo, São Paulo, n. 17, p. 237-260, 2008.

SILVA, Beatriz Pereira. Trajetória de luz e encanto: discursos e narrativas sobre Mãe Malvina (1970-2016, Florianópolis/SC). Dissertação (Mestrado em História) - Udesc, Florianópolis, 2016.

SILVA, Jaime José dos Santos. A dança do cacumbi: novo olhar sobre as festas afrobrasileiras e as vivências do pós-emancipação em Santa Catarina. In: ENCONTRO ESCRAVIDÃO E LIBERDADE NO BRASIL MERIDIONAL, 6., 2013, Florianópolis. Anais [...]. Florianópolis: UFSC, 2013.

SILVA, J. B. R. da; COSTA, M. da. Negros em Itajahy: da invisibilidade à visibilidade: mais de 150 anos de história. Itajaí: Casa Aberta, 2010. p. 89-107.

SILVA, José Bento Rosa da. Africanos na Foz do Itajaí/SC: nos séculos XIX e XX. In: COSTA, Moacir da; SILVA, José Bento Rosa da. Negros em Itajahy: da invisibilidade à visibilidade. Mais de 150 anos de história. Itajaí: Casa Aberta, 2010, p. 125-142.

SILVA, José Bento Rosa da. Congada de São Sebastião: uma manifestação da Cultura Luso-afro-brasileira na Armação do Itapocoroy/SC. In: COSTA, Moacir da; SILVA, José Bento Rosa da. Negros em Itajahy: da invisibilidade à visibilidade. Mais de 150 anos de história. Itajaí: Casa Aberta, 2010. p. 61-68.

SILVA, José Bento Rosa da. Memórias de um quilombo urbano: Itajaí/SC. In: COSTA, Moacir da; SILVA, José Bento Rosa da. Negros em Itajahy: da invisibilidade à visibilidade. Mais de 150 anos de história. Itajaí: Casa Aberta, 2010. p. 89-108.

TRAMONTE, Cristiana. Com a Bandeira de Oxalá! Trajetória, práticas e concepções das religiões afro-brasileiras na Grande Florianópolis. Itajaí: Univali, 2001. 